Pak. j. sci. ind. res. Ser. B: biol. sci. 2020 63B(2) 113-118

\title{
Amylase Production by Bacillus subtilis SY134D Strain Under Submerged Fermentation
}

\author{
Yasser Bakri*, Samir Elkhouri, Muhanad Harba and Yasser Akeed \\ Department of Molecular Biology and Biotechnology, AECS, P. O. Box 6091, Damascus, Syria \\ (received November 11, 2017; revised July 24, 2018; accepted September 18, 2018)
}

\begin{abstract}
Industrial important enzymes have traditionally been obtained by using submerged fermentation technology. Many organisms are able to produce these enzymes, but only a few of them exhibit satisfactory characteristics for industrial application. The ability of bacterial strains from the genus Bacillus to secrete large amounts of extracellular á-amylase has made them well suited for commercial production. Amylase production using Bacillus subtilis SY134D strain was conducted in flasks and bioreactor. In flasks, our results showed that soybean cake, beet pomace and tomato pomace were the best carbon source used in submerged fermentation $(\mathrm{SmF})$ after $72 \mathrm{~h}$ of incubation. In bioreactor, the rates of air flow and agitation speed are important factors that affect oxygen transfer rate which influence on product formation. When the aeration rate was increased from 0.25 to $0.75 \mathrm{vvm}$, amylase production increased at the speed of agitation 100 and $200 \mathrm{rpm}$. The best enzyme yield $127 \mathrm{IU} / \mathrm{mL}$ was obtained at $0.25 \mathrm{vvm}$ an aeration rate and $300 \mathrm{rpm}$ agitation speed in a 3L Electro-lab bio-reactor.
\end{abstract}

Keywords: Bacillus spp, $\alpha$-amylase, submerged fermentation, production.

\section{Introduction}

The hydrolytic enzymes are among the enzymes which increasing their industrial applications. Within these, $\alpha$-amylase receive special attention. Because of the importance of $\alpha$-amylase, commercial production began from 1940s and currently accounts for more than 30\% of the world's total enzyme production. $\alpha$-amylase plays a critical role in a wide variety of industries such as starch conversion processes, baking, brewing, bioalcohol, detergents, paper and textile desizing, pharmaceutical and sugar industries, therefore, efforts have been made to reduce its extraction and production costs (Haq et al., 2010; Sivaramakrishnan et al., 2006; Konsula and Kyriakides, 2004). Isolation of new microorganisms suitable for enzymes production could provide potential new sources of the enzyme (Aullybux and Puchooa, 2013). Among many micro-organisms Bacillus spp. is considered one of the most important sources of amylase (Rajput et al., 2013; Bakri et al., 2012) which supplies around $60 \%$ of the industrial world enzymes market (Burhan et al., 2003). The selection of a suitable substrate is critical for fermentation processes and investigating the potential of agro-wastes for producing amylase could lead to the availability of new alternative substrates for this purpose (Asrat and Girma, 2018). The industrial demand for most of the enzymes is met by the production using submerged fermentation $(\mathrm{SmF})$

*Author for correspondence; E-mail: ascientific@aec.org.sy
(Couto and Sanroman, 2006; Gangadharan et al., 2006; Kunamneni et al., 2005). The utilization of agro-residues for the production of enzymes has gained renewed interest as it solves solid waste disposal problem and also produces less wastewater (Aullybux and Puhooa, 2013). The production of enzymes on a large scale is mostly carried out by batch fermentation in stirred tank bio-reactors. The fermentation process with complex agro-residue as a substrate requires more adequate levels of aeration and agitation than a synthetic medium to facilitate optimum and uniform mass transfer due to particulate and fibrous nature of the substrate(Singh et al., 2014).

The aim of the present study was to evaluate a new bacterial strain, Bacillus subtilis SY134D for extracellular $\alpha$-amylase production under submerged fermentation condition in flask and in $3 \mathrm{~L}$ lab-bench scale fermenter.

\section{Materials and Methods}

Bacterial strain and growth conditions. Bacillus subtilis 134D used in this study was isolated from Syrian soil and selected as an á-amylase producing strain (Bakri et al., 2012). The strain was routinely cultured on nutrient agar plates (NA), incubated at $30{ }^{\circ} \mathrm{C}$ until bacterial colonies appear, kept at $4{ }^{\circ} \mathrm{C}$ and sub cultured every fifteen days. The inoculum was prepared by transferred aseptically a loopfull of Bacillus subtilis 
134D from nutrient agar plates to a sterilized $50 \mathrm{ml}$ tube with $20 \mathrm{ml}$ of nutrient broth medium. The incubation was carried out at $30{ }^{\circ} \mathrm{C}$ and rotated at $200 \mathrm{rpm}$ in a rotary shaker overnight. This prepared inoculum was used for the fermentation experiments.

Enzyme production using submerged fermentation (SmF). Amylase production was carried out in $100 \mathrm{~mL}$ Erlenmeyer flasks containing $25 \mathrm{~mL}$ of basal culture medium $(\mathrm{g} / \mathrm{L})\left(\mathrm{K}_{2} \mathrm{HPO}_{4}\right) 1 ;(\mathrm{NaCl})_{3} ;\left(\mathrm{MgSO}_{4} .7 \mathrm{H}_{2} \mathrm{O}\right)$ 0.3; (yeast extract) 3.0 and (peptone) 5.0 and the $\mathrm{pH}$ adjusted at 5 before sterilization. The flasks were sterilized at $120{ }^{\circ} \mathrm{C}$ for $20 \mathrm{~min}$. One milliliter of the prepared inoculum from the Bacillus SY134D was added to the sterilized medium and incubated at $30^{\circ} \mathrm{C}$ for 5 days in a rotary shaker (200 rpm). Fermented broth were then centrifuged for $10 \mathrm{~min}$ at $10000 / \mathrm{rpm}$, clear supernatant was collected and used as a crude enzyme.

Bioreactor cultivation conditions. A 3-L Electro-lab fermenter (Electro-lab limited, UK) was used as the base mechanical vessel for amylase production from Bacillus SY134D in batch culture. The agitation system is made of two Rushton turbine DT6. The diameter of these turbines was $d=50 \mathrm{~mm}$. The clearance above the base of the bio-reactor and the distance between the two turbines were equal to turbine diameter (d). The bio-reactor was filled with $1.5 \mathrm{~L}$ of culture medium and then sterilized at $121^{\circ} \mathrm{C}$ for $20 \mathrm{~min}$. After sterilization, the bio-reactor was inoculated with a $5 \%$ of prepared inoculum. A regulation system was used to control the temperature at $30^{\circ} \mathrm{C}$ throughout of the experiment. The fermentation medium contained $40 \mathrm{~g} / \mathrm{L}$ of soybean cake as a carbon source and the nutrients had the same concentrations that used in the flask experiment. The effects of agitation speed $(100,200,300$ and 400 $\mathrm{rpm} / \mathrm{min})$ and aeration rate $(0.25,0.50$ and $0.75 \mathrm{vvm})$ were examined. Foaming was controlled with the addition of $0.05 \%(\mathrm{v} / \mathrm{v})$ Tego antifoam KS911 (Goldschmidt, Essen, Germany). Fermentation was carried out for $96 \mathrm{~h}$ and the samples were withdrawn at $24 \mathrm{~h}$ intervals to check the enzyme production.

Amylase assay. $\alpha$-Amylase activity was determined as described by Okolo et al. (1995). The reaction mixture consisted of $1.25 \mathrm{~mL}$ of $1.0 \%$ soluble starch, $0.25 \mathrm{~mL}$ of $0.1 \mathrm{M}$ acetate buffer ( $\mathrm{pH} 5.0$ ), $0.25 \mathrm{~mL}$ of distilled water, and $0.25 \mathrm{~mL}$ of crude enzyme extract. After 10 minutes of incubation at $50{ }^{\circ} \mathrm{C}$, the liberated reducing sugars (glucose equivalents) were estimated by the dinitrosalicylic acid (DNS) method of Miller (1959). The blank contained $0.5 \mathrm{~mL}$ of $0.1 \mathrm{M}$ acetate buffer (pH 5.0), $1.25 \mathrm{~mL}$ of $1.0 \%$ starch solution and $0.25 \mathrm{~mL}$ of distilled water. One unit (IU) of $\alpha$-amylase is defined as the amount of enzyme releasing $1 \mu \mathrm{mol}$ glucose per minute under the assay conditions. All experiments were repeated twice.

\section{Results and Discussion}

The effect of carbon source on amylase production by Bacillus SY134D. The enzymes production by micro-organisms mainly depends on genetic nature of the organism, components of fermentation medium and their concentration and physiological growth conditions. Hence, the formulation of medium is an essential prerequisite to get higher productivity (Pandey et al, 2000). The concentration and nature of carbon source included in the culture medium plays a critical role in the growth of a micro-organism and its enzymes production. Some of the agricultural residues like wheat bran, wheat straw, tomato pomace, corn cobs hulls, cotton seed cake, beet pomace, soybean cake, olive seed cake, sawdust, corn starch, potato starch and molasses, and the following sugars: glucose, maltose, sucrose, mannitol, and lactose were studied to determine the best one for amylase production. Results showed different impact on amylase production with different substrates. Figure 1 demonstrates that soybean cake, tomato and beet pomace enhanced the alpha amylase production, while other sources particularly olive seed

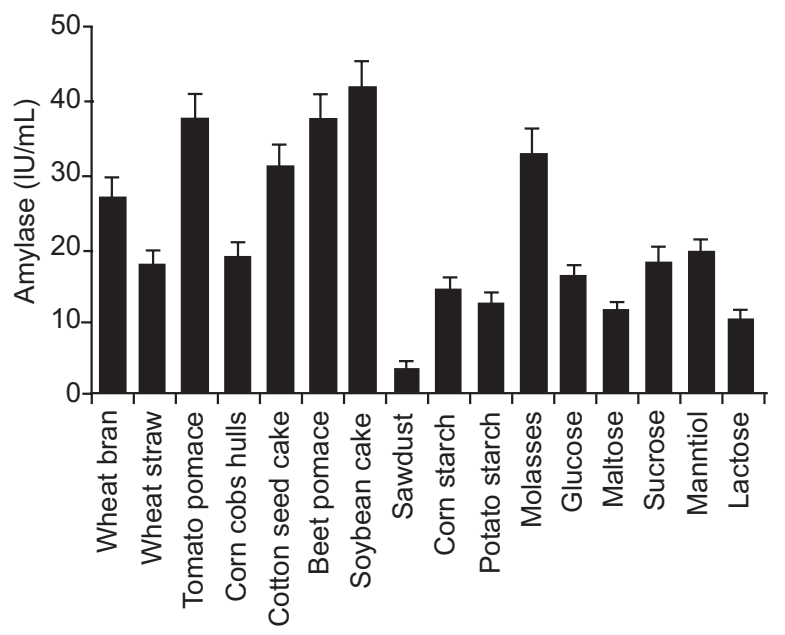

Fig. 1. The effect of carbon sources on amylase production by bacillus SY134D in SmF. 
cake and sawdust declined it, which might be due to the lack of starch in these substrates. On the other hand, molasses that enhanced amylase production in our work are considered as an important industrial waste for amylase production in several studies (Bhutto and Umar, 2011). Soybean cake was the best one among all used sources with $41.15(\mathrm{IU} / \mathrm{mL})$ which is in agreement with another scientific results which referred to a high yield of amylase enzyme using agro-industrial wastes (Prakash et al., 2009; Sexana et al., 2007).

The effect of soybean cake concentration on amylase production by bacillus SY134D. The optimum amount of substrate in the medium is an important factor due to its influence on the cost spending for any commercial products. A significant increase in amylase was seen when the substrate concentration increased in the culture medium from $1.0 \%(41.15 \mathrm{IU} / \mathrm{mL})$ to $4 \%(141.9 \mathrm{IU} / \mathrm{mL})$ (Fig. 2). In contrast, substrate abundance up to $5.0 \%$ decreased the production to 132.50 (IU/mL). Aiyer (2004) observed that Bacillus licheniformis SPT 27 had a decrease in amylase production when high substrate concentration (above 1.0\%). On other works, amylase production by Bacillus licheniformis showed an increase when starch concentration was lifted up till 5\% and up to $5 \%$ the amylase production decreased as reported by Oziengbe and Onilude (2012).

The effect of incubation time on amylase production by bacillus SY134D. The incubation time is a sensitive factor for any microorganism used in any industrial sector. Maximum enzyme production could be obtained only after a certain incubation time which allows the culture to grow at a study state (Pandey et al, 2000).

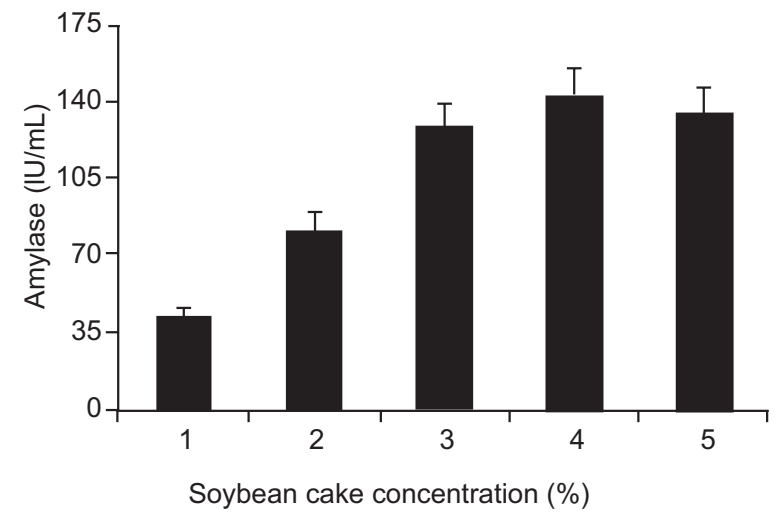

Fig. 2. The effect of soybean cake concentration on amylase production by bacillus SY134D in $\mathrm{SmF}$.
The specific growth rate of the strain. Growth rate and enzyme synthesis of the culture are the two main characteristics which are mainly influenced by incubation time (Ellaiah et al., 2002). The best yield of amylase production by Bacillus SY134D was at $72 \mathrm{~h}$ of incubation (Fig. 3). More time lead to a dramatic drop in amylase production since enzyme production depends mainly on the micro-organism conditions growth which is heavily affected by the lack of minerals in the medium. Several studies demonstrated the same results when worked on amylase production by $B$. licheniformis ATCC 12759 in submerged fermentation (Ackan et al., 2011; Nusrat et al., 2007).

Amylase production by bacillus SY134D in a 3-L bio-reactor. Oxygen transfer can often be very crucial parameter which determines the cell growth and product formation during fermentation due to its low solubility in the medium (Garcia-Ochoa and Gomez, 2009). Oxygen could be provided by aeration and agitation in the medium. Aeration rate and agitation speed are the main critical parameters for the growth and activation of micro-organisms in a bio-reactor. They are the sensitive factors used in a scaleup process and play an important role in the process productivity (Alves et al., 2010; Kao et al., 2007). Aeration activity affected by agitation speed causing more exchanging surfaces between gas/liquid resulting in oxygen abundance for cells( Jafari et al., 2007). Alpha amylase production by Bacillus SY134D in a 3L Bioreactor was increased at the agitation rates $100-200 \mathrm{rpm}$ when the aeration rate increased from 0.25 to $0.75 \mathrm{vvm}$ (Fig. 4 and 5). Many researchers reported a positive increasing aeration rate on enzyme production by micro-organisms (El-Enashasy

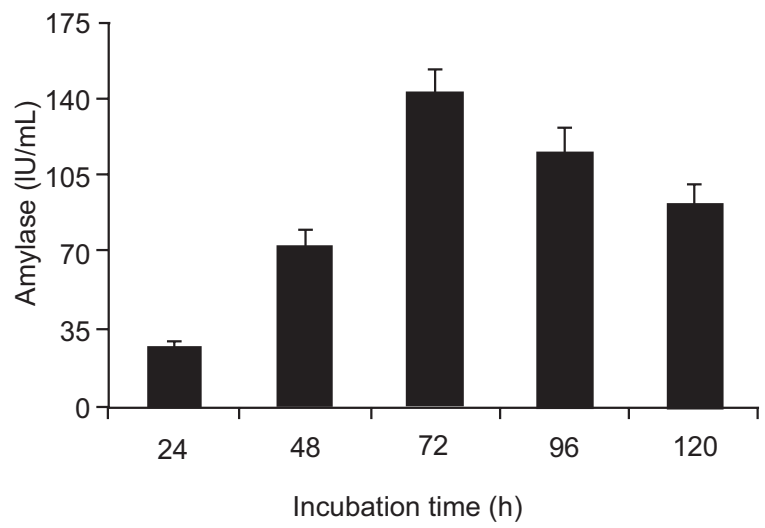

Fig. 3. The effect of incubation time on amylase production by bacillus SY134D in SmF. 


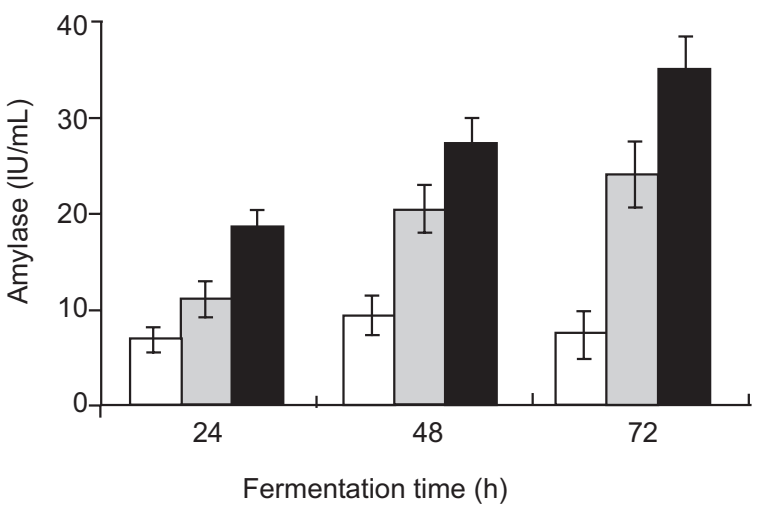

$\square$ Aeration rate $0.25 \mathrm{vvm} \square$ Aeration rate $0.5 \mathrm{vvm}$

Aeration rate $0.75 \mathrm{vvm}$

Fig. 4. $\alpha$-amylase production by Bacillus SY134D in a $3 \mathrm{~L}$ fermenter at $100 \mathrm{rpm}$ of agitation speed with different aeration rates.

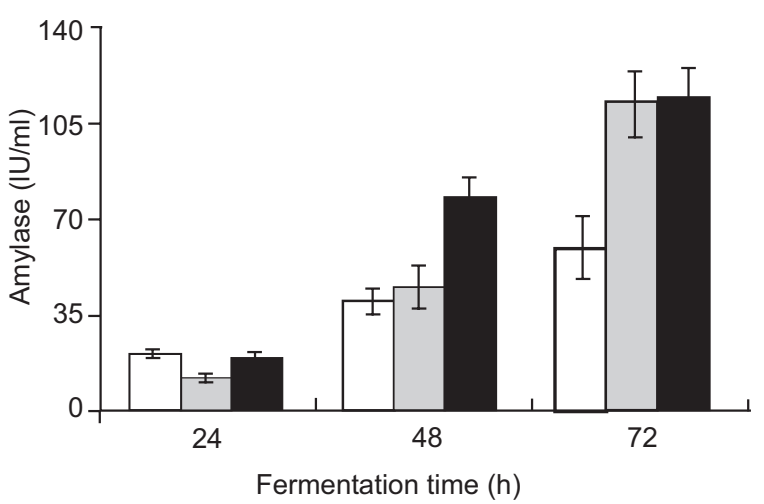

$\square$ Aeration rate $0.25 \mathrm{vvm} \square$ Aeration rate $0.5 \mathrm{vvm}$

Aeration rate $0.75 \mathrm{vvm}$

Fig. 5. $\alpha$-amylase production by Bacillus SY134D in a $3 \mathrm{~L}$ fermenter at $200 \mathrm{rpm}$ of agitation speed with different aeration rates.

et al., 2008; Jafari et al., 2007; Bakri et al., 2002). At an agitation rate of $300 \mathrm{rpm}$, amylase productivity increased as the aeration rate increased from 0.5 to 0.75 vvm after $48 \mathrm{~h}$ (Fig. 6). The maximum amylase production was $127 \mathrm{IU} / \mathrm{mL}$ at $0.25 \mathrm{vvm}$ aeration rate and $300 \mathrm{rpm}$ agitation speed after $48 \mathrm{~h}$.

\section{Conclusion}

This study demonstrates the effective using agro-residual substrates for industrial enzyme production. The maximum yield of amylase production by Bacillus SY134D was found in soybean cake at a concentration

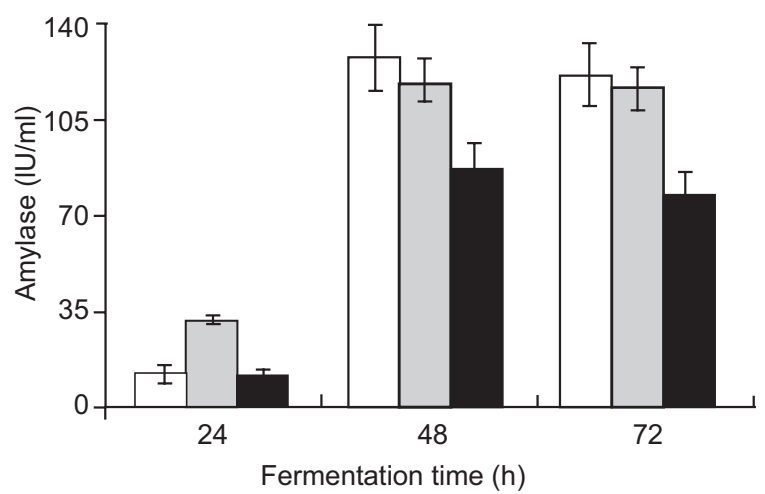

Aeration rate $0.25 \mathrm{vvm} \square$ Aeration rate $0.5 \mathrm{vvm}$

Aeration rate $0.75 \mathrm{vvm}$

Fig. 6. $\alpha$-amylase production by Bacillus SY134D in a $3 \mathrm{~L}$ fermenter at $300 \mathrm{rpm}$ of agitation speed with different aeration rates.

of $4 \%$. In a scaleup process, the results clearly demonstrate the importance of aeration and agitation on amylase production. The best enzyme production was obtained at aeration rate of $0.25 \mathrm{vvm}$ and agitation speed of $300 \mathrm{rpm}$.

\section{Acknowledgement}

The authors would like to thank the General Director of AECS and the Head of Biotechnology Department for their help through the time of this work. Thanks are also extended to Dr.A.Aldaoude for a critical reading of the manuscript.

Conflict of Interest. The authors declare no conflict of interest

\section{References}

Aiyer, P.V.D. 2004. Effect of C: $\mathrm{N}$ ratio on alpha amylase production by Bacillus licheniformis SPT 27. African Journal of Biotechnology, 3: 519-522.

Akcan, N., Uyar, F., Guven, A. 2011. Alpha-amylase production by Bacillus subtilis RSKK96 in submerged cultivation. Kafkas Üniversitesi Veteriner Fakültesi Dergisi, 17: 17-22.

Alves, F.G., Filho, F.M., de Medeiros Burkert, J.F. 2010. Maximization of beta-galactosidase production: a simultaneous investigation of agitation and aeration effects. Applied Biochemistry and Biotechnology, 160: 1528-1539.

Asrat, B., Girma, A. 2018. Isolation, production and characterization of amylase enzyme using the isolate 
Aspergillus niger FAB-211. International Journal of Biotechnology and Molecular Biology Research, 9: 7-14.

Aullybux, A., Puchooa, D. 2013. á-Amylase production on low-cost substrates by Naxibacter sp. isolated from mauritian soils. British Microobiology Research, 3: 478-491.

Bakri, Y., Ammouneh, H., El-Khouri, S., Harba, M., Thonart, P. 2012. Isolation and Identification of a new Bacillus strain for amylase production. Research in Biotechnology, 3: 51-58.

Bakri, Y., Jacques, P., Shi, L K., Thonart, P. 2002. Influence of a new axial impeller on KLa and xylase production by Penicillium canescens 1010c. Applied biochemistry and biotechnology, 98: 1037-1048.

Bhutto, M.A., Umar, M.D. 2011. Effect of alternative carbon and nitrogen sources on production of $\alpha$ amylase by Bacillus megaterium. World Applied Sciences Journal, 13: 85-90.

Burhan, A., Nisa, U., Gokhan, C., Ashabil, A., Osmair, G. 2003. Enzymatic properties of a novel thermostable thermophilic alkaline and chelator resistant amylase from an alkaphilic Bacillus $\mathrm{sp}$ isolate ANT-6. Process Biochemistry, 38: 13971403.

Couto, S.R., Sanroman, M.A. 2006. Application of solid-state fermentation to food industry - a review. Journal of Food Engineering, 76: 291-302.

El-Enshasy, H., Abuoul-Enein, A., Helmy, S., El-Azaly, Y. 2008. Optimization of the industrial production of alkaline protease by Bacillus licheniformis in different production scales. Australian Journal of Basic and Applied Sciences, 2: 583-593.

Ellaiah, P., Adinarayana, K., Bhavani, Y., Padmaja, P., Srinivasulu, B. 2002. Optimization of process parameters for gluco-amylase production under solid state fermentation by a newly isolated Aspergillus species. Process Biochemistry, 38: 615620.

Gangadharan, D., Sivaramakrishnan, S., Namboothiri, K.M., Pandey, A. 2006. Solid culturing for Bacillus amyloliquefaciens for $\alpha$-amylase production. Food Technology and Biotechnology, 44: 269-274.

Garcia-Ochoa, F., Gomez, E. 2009. Bioreactor scaleup and oxygen transfer rate in microbial processes: An Overview, Biotechnology Advances, 27: 153176

Haq, I.U., Muhammad, M.J., Uzma, H., Fazal, A. 2010. Kinetics and thermodynamic studies of alpha amylase from Bacillus licheniformis mutant. Pakistan Journal of Botany, 42: 3507-3516.

Jafari, A.R., Sarrafzadeh, M.H., Alemzadeh, I., Vosoughi, M. 2007. Effect of stirrer speed and aeration rate on the production of glucose oxidase by Aspergillus niger. Journal of Biological Sciences, 7: 270-275.

Kao, P.M., Chen, C.I., Huang, S.C., Chang, Y.C., Tsai, P.J., Liu, Y,C. 2007. Effects of sheer stress and mass transfer on chitinase production by Paenibacillus sp. CHE-N1. Biochemical Engineering Journal, 34: 172-178.

Konsula, Z., Kyriakides, L.M. 2004. Hydrolysis of starches by the action of an a-amylase from Bacillus subtilis. Process Biochemistry, 39: 1745-1749.

Kunamneni, A., Permaul, K., Singh, S. 2005. Amylase production in solid state fermentation by the thermophilic fungus Thermomyces lanuginosus. Journal of Bioscience and Bioengineering, 100: 168-171.

Miller, G.L. 1959. Use of dinitrosalicylic acid reagent for determination of reducing sugars. Analytical Chemistry, 31: 426-428.

Nusrat, A., Rahman, S.R. 2007. Comparative studies on the production of extracellular $\alpha$-amylase by three mesophilic Bacillus isolates. Bangladesh Journal of Microbiology, 24: 129-132.

Okolo, B.N., Ezeogu, L.I., Mba, C.N. 1995. Production of raw starch digestive amylase by Aspergillus niger grown on native starch source. Journal of the Science of Food and Agriculture, 69: 109-115.

Oziengbe, E.O., Onilude, A.A. 2012. Production of a thermostable $\alpha$-amylase and its assay using Bacillus licheniformis isolated from excavated land sites in Ibadan, Nigeria. Bayero Journal of Pure and Applied Sciences, 5: 132-138.

Pandey, A., Nigam, P., Soccol, C.R., Socool, V.T., Singh, D., Mohan, R. 2000. Advances in microbial amylases. Biotechnology and Applied Biochemistry, 31: 135-152.

Prakash, B., Vidyasagar, M., Madhukumar, M.S., Muralikrishna, G., Sreeramulu, K. 2009. Production, purification and characterization of two extremely halo-tolerant, thermostable, and alkali-stable $\alpha$ amylases from Chromohalobacter sp. TVSP 101. Process Biochemistry, 44: 210-215.

Rajput, I.R., Li, W.F., Li, Y.L., Jian, L., Wang, M.Q. 2013. Application of probiotic (Bacillus subtilis) to enhance immunity, antioxidation, digestive enzymes activity and hematological profile of 
Shaoxing duck. Pakistan Veterinary Journal, 33: 69-72.

Sexana, R., Dutt, K., Agarwal, L., Nayyar, P., Ayyar, P. 2007. A highly thermostable and alkaline amylase from a Bacillus sp. PN5. Bioresource Technology, 98: $260-265$.

Singh, P., Singh, R., Gupta, P., Shrivastava, A.K. 2014. $\alpha$-Amylase production by Bacillus amylo- liquefaciens using agro wastes. International Journal of Pharmacy and Life Sciences, 5, 32653269.

Sivaramakrishnan, S.,Gangadharan, D., Nampoothiri, K.M., Soccol, C.R., Pandey, A. 2006. $\alpha$-amylase from microbial sources -an overview on recent developments. Food Technology and Biotechnology, 44: $173-184$. 